\title{
max \\ Pollen Production of Selected Grass Species in Russia and India at the Levels of Anther, Flower and Inflorescence
}

\author{
Elena Severova ${ }^{1, *(D)}$, Yury Kopylov-Guskov ${ }^{1,2} \mathbb{D}$, Yulia Selezneva ${ }^{3}$, Vera Karaseva ${ }^{3}$ (D) Shrirang R. Yadav ${ }^{4}$ \\ and Dmitry Sokoloff 1
}

1 Department of Higher Plants, Biological Faculty, M.V. Lomonosov Moscow State University, 119234 Moscow, Russia; yurez-kg@yandex.ru (Y.K.-G.); sokoloff-V@yandex.ru (D.S.)

2 Faculty of Biology, Shenzhen MSU-BIT University, Shenzhen 518172, China

3 Institute of Natural Science, S.A. Esenin Ryazan State University, 390000 Ryazan, Russia; posevina_julia@mail.ru (Y.S.); v.karaseva@365.rsu.edu.ru (V.K.)

4 Angiosperm Taxonomy Laboratory, Department of Botany, Shivaji University, Kolhapur 416004, India; sryadavdu@rediffmail.com

* Correspondence: elena.severova@mail.ru; Tel.: +7-915-3884349

check for

updates

Citation: Severova, E.;

Kopylov-Guskov, Y.; Selezneva, Y.; Karaseva, V.; Yadav, S.R.; Sokoloff, D. Pollen Production of Selected Grass Species in Russia and India at the Levels of Anther, Flower and Inflorescence. Plants 2022, 11, 285. https://doi.org/10.3390/ plants11030285

Academic Editor: Andrew McCubbin

Received: 23 December 2021

Accepted: 18 January 2022

Published: 21 January 2022

Publisher's Note: MDPI stays neutral with regard to jurisdictional claims in published maps and institutional affiliations.

Copyright: (c) 2022 by the authors. Licensee MDPI, Basel, Switzerland. This article is an open access article distributed under the terms and conditions of the Creative Commons Attribution (CC BY) license (https:// creativecommons.org/licenses/by/ $4.0 /)$.

\begin{abstract}
Grasses produce large amounts of pollen and are among the main causes of pollen allergy worldwide. Quantification of the roles of individual grass species in airborne pollen is an important task, because morphologically indistinguishable pollen grains of different species may differ in allergenicity. This requires knowledge of the pollen production of individual grass species; however, accumulated data are insufficient in this respect. Attempting to fill this gap, we studied pollen production per inflorescence in 29 grass species which are widespread in Middle Russia and India. Pollen production per inflorescence is determined by the number of grains per anther, the number of flowers in a spikelet and the number of spikelets per inflorescence, with the latter parameter being the most variable. We support the hypothesis that pollen production per inflorescence differs significantly between annual and perennial grasses. The greater pollen production of perennials can be interpreted as a tendency to guarantee cross-fertilization of species with self-incompatibility. The inferred pollen/ovule $(\mathrm{P} / \mathrm{O})$ ratios suggest the occurrence of facultative xenogamy in all annuals and obligate xenogamy in most perennials in the present dataset, though some self-incompatible annuals exist outside our sampling. Earlier data indicated that the $\mathrm{P} / \mathrm{O}$ ratio of the annual cereal crop rye (Secale cereale) is higher than in any annual or perennial species sampled here. A ratio of pollen production to seed set ( $\mathrm{P} / \mathrm{S}$ ratio) is suggested to be another efficient parameter in reproductive biology of grasses. We highlight a need for detailed studies of reproductive biology in grasses that include both pollen and seed production. We found a correlation between pollen production per anther and anther length. A rough approximation of c. 1000 pollen grains per $1 \mathrm{~mm}$ of the length of an anther provides an instrument for estimates of pollen production in plant communities.
\end{abstract}

Keywords: pollen; Poaceae; pollen/ovule ratio; reproductive biology; Europe; tropical Asia; nrITS

\section{Introduction}

Grasses (Poaceae) make up the second-largest monocot family, comprising more than 11,000 species worldwide [1]. The importance of this group lies not only in the number of species and their wide distribution; interactions between grasses and humans are multidimensional, and go far beyond their use as crop cereals [2,3] and pasture plants [4]. Grasses produce a large amount of pollen, and are among the main causes of pollen allergies [5,6]. To date, eleven groups of grass pollen allergens have been identified; groups 1 and 5 are responsible for most (up to 95\%) cases of the grass allergy [7].

The very high pollen production characteristic of many grass species is related to their reproductive strategy. Most grasses are anemophilous [8,9] with the exceptions of some cleistogamous and a few entomophilous species [10]. Cleistogamy was reported in some 
tropical as well as temperate grasses, including several varieties of the most important cereal crop, wheat [11-13]. For a number of species, mainly from the tropics, environmental control of cleistogamy was found [14-17]. Entomophily is documented or suspected to occur in some tropical grasses, as in the absence of air movement under the canopy of a tropical forest, anemophily is inefficient [14]. Soderstrom and Calderon [18] described pollination by flies and gall midges of species of Parianum and Olyra in tropical South America. Pollen of Parianum has a well-sculpted exine [18], which agrees with the idea of the occurrence of entomophily in this taxon. Various insects were observed as visitors of anthetic inflorescences of other tropical grasses [19-26], but their participation in effective pollination was not always obvious. Besides reproductive strategies and local conditions, pollen production -of grass species depends on the life form (annual or perennial). Perennial grasses are known to produce more pollen than annuals [27-29].

Pollen production of grass species has been estimated previously as a part of research on pollination biology [30-34], seed production [35], the breeding and selection of domesticated cereal grasses [36-39] and aerobiology [27,28,40-42]. Pollen production per anther can differ significantly between species, as well as among different populations of the same species. A good (and almost the only) example of pollen production estimation of a species occurring in multiple climatic and geographical conditions is available for Dactylis glomerata. Its pollen production can differ significantly in different regions, i.e., from 1300-1800 pollen grains (pg)/anther [40,42] to 3000-3500 pg/anther [27,32].

Investigations of grass pollen production are in great demand in aerobiology. Airborne pollen monitoring is of a primary importance for the interpretation of allergy data and therapy planning, but also for agronomy, environmental health, forestry etc. [5]. Poaceae is a stenopalynous family. It is impossible to distinguish among the pollen grains of different grass genera, let alone species, using light microscopy [43]. Pollen curves and calendars obtained by routine aerobiological monitoring normally identify grasses as one group. The determination of the precise flowering times of different species and their pollen concentrations may be very important for allergy sufferers as, despite the lack of detailed studies, it is assumed that different grass species may have pollen grains with different degrees of allergenicity [44]. Refining data on grass pollination period down to the species level is possible either on the basis of phenological observations [29] or by metabarcoding [45-48]. Both approaches need data on the pollen production of different species to determine the impact of individual species and validate the results.

Another factor closely related to investigations of pollen production is potential correlations between the number of pollen grains per anther, anther length and pollen size. Grasses (and sedges) produce pollen in an unusual manner. The microspores and then pollen grains form a single layer around the secretory tapetum, so that any single pollen grain has a direct contact between its distal aperture and tapetal cells [49-51]. In general, such a location restricts the number of pollen grains per locule. Friedman and Harder [52] discovered a positive correlation between pollen size and the number of pollen grains per anther and total volume of pollen per flower. They hypothesized that "species with large pollen invest more in pollen than species with small pollen. (...) This greater investment may signal compensation for lower pollination efficiency (proportion of removed pollen grains exported to stigmas)" [52]. However, this hypothesis needs to be tested. Revealing correlations between pollen size and anther length may be important from an agricultural point of view, i.e., in the search for good pollen donors for hybridization. Such study was carried out for wheat varieties [39], revealing positive correlations between these parameters. Detailed studies of variation in pollen yield in five species of Bromus revealed that anther length is an excellent predictor of pollen production in this genus [34]. A link between anther length and pollen production was found in Triticum, Secale and their hybrid Triticale [36-39].

Despite the importance of data on the pollen production of individual species of grasses, they are still fragmentary. Most studies performed so far have been concentrated on grasses in particular geographical regions. It is therefore difficult to say to what extent 
their conclusions can be generalized and used elsewhere. The present study is intended to contribute another dataset regarding the pollen production of grasses, and one that would make it possible to perform large-scale comparisons.

To investigate the pollen production of grasses with different life forms and possibly different reproductive strategies, we selected two regions with contrasting climatic conditions: Central Russia (temperate continental climate) and the Western Ghats region near Kolhapur, Maharashtra (India) (tropical monsoon climate) [53]. In Central Russia, we chose two sampling areas, Moscow oblast and Ryazan oblast within the same climatic zone [53], to evaluate the variability of pollen production within a biogeographical region. The pollen production of the grasses of Maharashtra, Moscow oblast and Ryazan oblast has never been studied before. There are 415 species of grasses recorded in Maharashtra [54]. The flora of Central Russia includes 270 species of grasses [55]. The most complete study of grass pollen production in India was carried out by Subba Reddy and Reddy [31] in Andhra Pradesh, and covered 54 species. The state of Andhra Pradesh is situated at the eastern part of peninsular India and includes a considerable part of Eastern Ghats. Investigations of grass pollen production in Central Russia are even more incomplete than in India. We found the only study with data on the pollen production of eleven grass species from Saratov oblast [32]. The aim of our study was (1) to evaluate pollen production per inflorescence in common grass species in Maharashtra and Middle Russia [54,55]; (2) to compare the pollen production of species with different life forms; (3) to evaluate the variability of all traits that determine pollen production; and (4) to determine whether pollen production is correlated with the size of pollen grains and anther length in a large-scale analysis that includes various grass species that differ in ecology and reproductive biology.

\section{Material and Methods}

\subsection{Sampling Areas}

The plants were collected in Kolhapur $\left(16^{\circ} 41^{\prime} \mathrm{N}, 74^{\circ} 14^{\prime} \mathrm{E}\right)$ and surrounding parts of the Maharashtra state (India), Moscow $\left(55^{\circ} 45^{\prime} \mathrm{N}, 37^{\circ} 37^{\prime} \mathrm{E}\right)$ and Ryazan $\left(54^{\circ} 36^{\prime} \mathrm{N}, 39^{\circ} 42^{\prime} \mathrm{E}\right)$ and their surroundings (Russia) from sites comprising different grass habitats, mainly in cities and suburbs, i.e., recreation areas (parks, botanical gardens), lawns and wastelands. These habitats were selected as we assume their primary roles in the production of allergic pollen affecting the local population.

\subsection{Species Identification}

The species were identified using local floras $[54,55]$. The taxonomy of a number of tropical grass groups is still far from being stable due to the lack of global revisions utilizing extensive molecular phylogenetic data. Anticipating possible future taxonomic adjustments, in addition to traditional herbarium vouchers, we generated nrITS sequences of all accessions of Indian grass species studied here and deposited them in GenBank. These can be used as molecular vouchers in any potential complex taxonomic situations. We extracted DNA from dried leaves using DiamondDNA Plant Kit ("AltaiBioTech" Ltd., Barnaul, Russia) according to the manufacturer's protocol. The quality and concentration of the extracted DNA were evaluated with a spectrophotometer. We amplified the nuclear complete ITS region with ITS4 and ITS5 primers [56]. The reaction mix $(20 \mu \mathrm{L})$ contained 10-30 ng of template DNA, 5 pmol of each primer and MasDDTaqMIX ready-to-use mix: (200 $\mu \mathrm{M}$ of each dNTP, 2.0 mM MgC12, 1.5 unit of Taq-polymerase, buffer solution; "Dialat" Ltd., Moscow, Russia). PCR conditions were as follows: 5 min at $95{ }^{\circ} \mathrm{C}$-preliminary denaturation; 30 cycles of: $30 \mathrm{~s}$ at $95^{\circ} \mathrm{C}$-denaturation, $30 \mathrm{~s}$ at $54^{\circ} \mathrm{C}$-primer annealing, $40 \mathrm{~s}$ at $72{ }^{\circ} \mathrm{C}$-elongation; $7 \mathrm{~min}$. at $72{ }^{\circ} \mathrm{C}$-final elongation. Amplicons were purified with CleanUp Mini Kit ("Evrogen" Ltd., Moscow, Russia). Commercial service of Sanger sequencing was provided by the "Evrogen" Ltd. (Moscow, Russia). All obtained sequences we manually checked by comparing with chromatograms in the MEGA X software [57]. 
A total of 15 species which are widespread in Middle Russia and 14 Indian species were studied. All studied species with voucher information are listed in Table 1. Voucher specimens were deposited in the Herbarium of Moscow University (MW).

Table 1. Material used in the present study.

\begin{tabular}{|c|c|c|c|}
\hline Species & $\begin{array}{l}\text { Voucher Information and GenBank } \\
\text { Accession Numbers for ITS1-2 Sequences }\end{array}$ & Locality, Sampling Date & Life Form \\
\hline Alopecurus pratensis L. & Severova s.n. (MW 1072500) & $\begin{array}{l}\text { Lomonosov Moscow State University, } \\
\text { Moscow, Russia, } 28 \text { May } 2021\end{array}$ & perennial \\
\hline $\begin{array}{l}\text { Arrhenatherum elatius (L.) P. Beauv. ex } \\
\text { J. \& C. Presl. }\end{array}$ & Severova s.n. (MW 1072498) & as above, 11 June 2021 & perennial \\
\hline Arthraxon hispidus (Thunb.) Makino & Sokoloff et al. 127 (MW 0758387), OL752458 & $\begin{array}{l}\text { Shivaji University, Botanical Garden, } \\
\text { Kolhapur, India, } 31 \text { August } 2019\end{array}$ & annual \\
\hline Bromus inermis Leyss. & Severova s.n. (MW 1072504) & $\begin{array}{l}\text { 1. Lomonosov Moscow State University, } \\
\text { Moscow, Russia, } 11 \text { June } 2021 \\
\text { 2. Sovetskyi rayion, Ryazan, Russia, } \\
8 \text { June } 2021\end{array}$ & perennial \\
\hline Calamagrostis epigeios (L.) Roth & Severova s.n. (MW 1072496) & $\begin{array}{l}\text { 1. as above, } 9 \text { July } 2021 \\
\text { 2. Deulino, Ryazan' oblast, Russia, } \\
5 \text { July } 2020\end{array}$ & perennial \\
\hline Chloris barbata Sw. & Sokoloff et al. 87 (MW 0758380); OL752448 & $\begin{array}{l}\text { Shivaji University, Botanical Garden, } \\
\text { Kolhapur, India, } 29 \text { August } 2019\end{array}$ & annual \\
\hline Chloris virgata Sw. & Sokoloff et al. 93 (MW 0758383); OL752452 & as above, 29 August 2019 & annual \\
\hline Dactylis glomerata L. & Severova s.n. (MW 1072497) & $\begin{array}{l}\text { 1. Lomonosov Moscow State University, } \\
\text { Moscow, Russia, } 28 \text { May } 2021 \\
\text { 2. Sovetskyi rayion, Ryazan, Russia, } \\
9 \text { June } 2020\end{array}$ & perennial \\
\hline Dactyloctenium aegyptium (L.) Willd. & Sokoloff et al. 88 (MW 0758384); OL752449 & $\begin{array}{l}\text { Shivaji University, Botanical Garden, } \\
\text { Kolhapur, India, } 29 \text { August } 2019\end{array}$ & annual \\
\hline Digitaria ciliaris (Retz.) Koeler & Sokoloffet al. 92 (MW 0758386); OL752451 & as above, 29 August 2019 & annual \\
\hline Digitaria sanguinalis (L.) Scop. & Severova s.n. (MW 1072506) & $\begin{array}{l}\text { Lomonosov Moscow State University, } \\
\text { Moscow, Russia, } 4 \text { October } 2021\end{array}$ & annual \\
\hline $\begin{array}{l}\text { Digitaria stricta Roth ex } \\
\text { Roem. \& Schult. }\end{array}$ & Sokoloff et al. 98 (MW 0758385); OL752455 ** & $\begin{array}{l}\text { Shivaji University, Botanical Garden, } \\
\text { Kolhapur, India, } 29 \text { August } 2019\end{array}$ & annual \\
\hline Echinochloa colona (L.) Link & Sokoloff et al. 86 (MW 0758390); OL752447 & as above, 29 August 2019 & annual \\
\hline Echinochloa crus-galli (L.) P. Beauv. & Severova s.n. (MW 1072505) & $\begin{array}{l}\text { Marfino, Moscow, Russia, } \\
4 \text { October } 2021\end{array}$ & annual \\
\hline Eleusine indica (L.) Gaertn. & Sokoloff et al. 97 (MW 0758388); OL752454 & $\begin{array}{l}\text { Shivaji University, Botanical Garden, } \\
\text { Kolhapur, India, } 29 \text { August } 2019\end{array}$ & annual \\
\hline Elymus repens (L.) Gould & Severova s.n. (MW 1072493) & $\begin{array}{l}\text { 1. Lomonosov Moscow State University, } \\
\text { Moscow, Russia, } 28 \text { May } 2021 \\
\text { 2. Deulino, Ryazan oblast, Russia, } \\
\text { 10 June } 2020\end{array}$ & perennial \\
\hline Festuca pratensis Huds. & Severova s.n. (MW 1072495) & $\begin{array}{l}\text { 1. as above, } 28 \text { May } 2021 \\
\text { 2. Sovetskyi rayion, Ryazan, Russia, } \\
10 \text { June } 2020\end{array}$ & perennial \\
\hline Isachne elegans Dalzell & Sokoloff et al. 156 (MW 0758391); OL752459 ** & $\begin{array}{l}\text { Western Ghats, Maharashtra State, India, } \\
2 \text { September } 2019\end{array}$ & perennial \\
\hline Iseilema hackelii Shrestha et Gandhi & Sokoloff et al. 108 (MW 0758392); OL752456 * & $\begin{array}{l}\text { Western Ghats, Maharashtra State, } \\
\text { Satara District, India, } 30 \text { August } 2019\end{array}$ & perennial \\
\hline Lolium perenne L. & Severova s.n. (MW 1072494) & $\begin{array}{l}\text { 1. Lomonosov Moscow State University, } \\
\text { Moscow, Russia, } 28 \text { May } 2021 \\
\text { 2. Sovetskyi rayion, Ryazan, Russia, } \\
\text { 12 June } 2020\end{array}$ & perennial \\
\hline
\end{tabular}


Table 1. Cont.

\begin{tabular}{|c|c|c|c|}
\hline Species & $\begin{array}{c}\text { Voucher Information and GenBank } \\
\text { Accession Numbers for ITS1-2 Sequences }\end{array}$ & Locality, Sampling Date & Life Form \\
\hline Phleum pratense $\mathrm{L}$. & Severova s.n. (MW 1072502) & $\begin{array}{l}\text { 1. as above, } 28 \text { May } 2021 \\
\text { 2. as above, } 12 \text { June } 2020\end{array}$ & perennial \\
\hline Pоа аппиа L. & Severova s.n. (MW 1072501) & $\begin{array}{l}\text { 1. as above, } 28 \text { May } 2021 \\
\text { 2. as above, } 6 \text { June } 2020\end{array}$ & $\begin{array}{c}\text { annual or } \\
\text { short-living } \\
\text { perennial }\end{array}$ \\
\hline Poa pratensis $\mathrm{L}$. & Selezneva, Karaseva s.n. (MW 1072499) & $\begin{array}{l}\text { Sovetskyi rayion, Ryazan, Russia, } \\
10 \text { June } 2020\end{array}$ & perennial \\
\hline Poa trivialis L. & Severova s.n. (MW) & $\begin{array}{l}\text { 1. Lomonosov Moscow State University, } \\
\text { Moscow, Russia, } 28 \text { May } 2021 \\
\text { 2. Ryazan, Russia, } 10 \text { June } 2020\end{array}$ & perennial \\
\hline Setaria intermedia Roem. \& Schult. & Sokoloff et al. 95 (MW 0758381); OL752453* & $\begin{array}{l}\text { Shivaji University, Botanical Garden, } \\
\text { Kolhapur, India, } 29 \text { August } 2019\end{array}$ & annual \\
\hline Setaria pumila (Poir.) Roem. \& Schult. & Severova s.n. (MW 1072503) & $\begin{array}{l}\text { Lomonosov Moscow State University, } \\
\text { Moscow, Russia, } 4 \text { October } 2021\end{array}$ & annual \\
\hline Tripogon jacquemontii Stapf & Sokoloff et al. 111 (MW 0758389); OL752457 & $\begin{array}{l}\text { Western Ghats, Maharashtra State, } \\
\text { Satara District, India, } 30 \text { August } 2019\end{array}$ & perennial \\
\hline Urochloa panicoides P. Beauv. & Sokoloff et al. 85 (MW 0758379); OL752446* & $\begin{array}{l}\text { Shivaji University, Botanical Garden, } \\
\text { Kolhapur, India, } 29 \text { August } 2019\end{array}$ & annual \\
\hline Urochloa ramosa (L.) T.Q. Nguyen & Sokoloff et al. 90 (MW 0758382); OL752450 & as above, 29 August 2019 & annual \\
\hline
\end{tabular}

*, first ITS1-2 sequence for the species in the GenBank database; ${ }^{* *}$, first sequence for the species in the GenBank database overall.

\subsection{Estimation of Pollen Production}

The method for pollen production estimation was chosen according to the objectives of our research. When studying the breeding systems and reproductive strategies of particular species, pollen production per anther or per flower is usually calculated [31,32]. For aerobiological monitoring, it is important to estimate pollen production of each species in a certain territory; as such, different methods of abundance estimation are used [27,28,42]. In our study, we estimated pollen production per inflorescence. Our approach allowed us to use the results in both areas, namely, to investigate the reproductive strategies of species and to evaluate pollen production per territory, as the number of inflorescences and their densities in various types of vegetation can be relatively easily counted in the field. To estimate pollen production per inflorescence, we investigated several parameters. The mean number of spikelets was calculated based on 20 inflorescences for Russian species and 10 for Indian species. To determine the number of flowers per inflorescence, we selected three spikelets from each inflorescence. The number of flowers per inflorescence was obtained by multiplying the average number of flowers/spikelets by the average number of spikelets/inflorescence. To calculate the total number of pollen grains per anther, a mature pre-anthetic flower from each inflorescence was selected. The number of pollen grains was estimated using a method of Kaybeleva and Yudakova [32]. Each anther was crushed on a glass slide to create a pollen monolayer in a drop of water, which was then studied and photographed under light microscope Nikon Eclipse Ci (Nikon GMBH, Dusseldorf, Germany). Pollen was counted using the Adobe Photoshop software [58]. Arrhenatherum elatius has dimorphic fertile flowers in a spikelet, with one flower being male and the other bisexual. As studies of another grass with dimorphic flowers, Hierochloe, revealed functional differences between the anthers of female-fertile and female-sterile flowers, at least in some species [59], we calculated pollen production per anther independently for these flower types in Arrhenatherum. Total pollen production per inflorescence was calculated by multiplying the number of pollen grains per anther by the number of anthers per flower by the number of flowers per inflorescence. We determined a variance of total pollen production per inflorescence according to a formula for variance of product of random variables. To estimate the average anther length, 10-20 anthers from different 
inflorescences were measured with a Nikon Eclipse Ci microscope (Japan). The exact sample sizes for each species are shown on Figure 1. The anther length was defined as the length of its longer theca when the two thecae were of unequal length. The biggest diameter of pollen grains was measured on temporary slides in water under a light microscope. At least 20 nonacetolyzed pollen grains of each species were studied. We used the Student's t-test and Tukey's HSD test to make pairwise and multiple comparisons, respectively, and linear coefficients of correlation to describe connections among variables (Pearson's $r$ for parametric and Spearman's rho for nonparametric data). Data analyses were performed in R 4.0.5 [60].

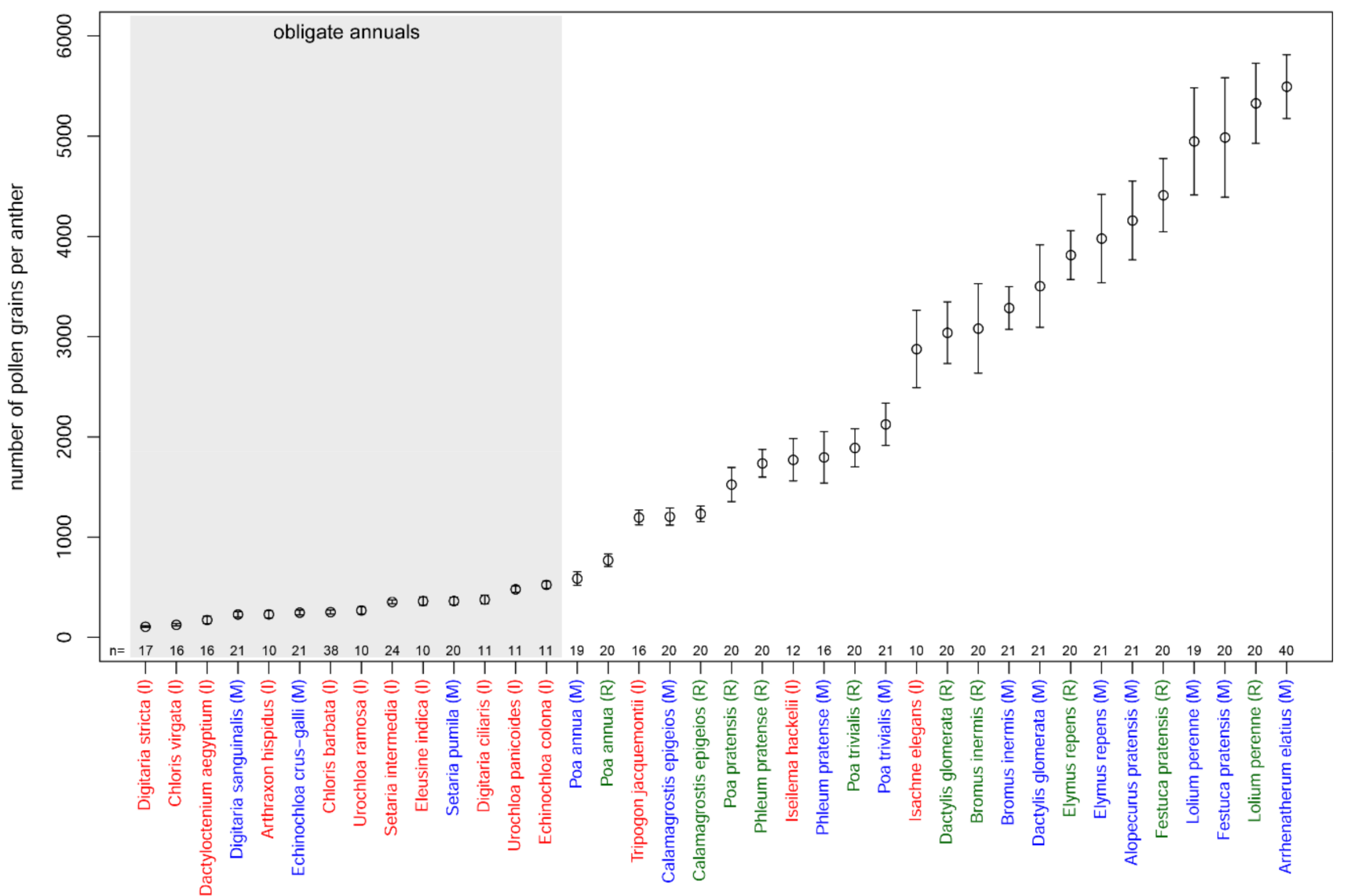

Figure 1. Pollen production per anther in studied samples; $n=$ the number of anthers examined in each species. Mean values and their $95 \%$ confidence intervals are shown. Colors indicate samples from different regions: red (I), India; green (R), Ryazan; blue (M), Moscow.

\section{Results}

\subsection{ITS1-2 Sequencing}

For all 14 species from India examined here, the ITS1-2 region was successfully amplified and sequenced. The sequences deposed in GenBank were the result of combining two raw sequences (derived from forward and reverse primers). For five species (Digitaria stricta, Isachne elegans, Iseilema hackelii, Setaria intermedia, Urochloa panicoides), these were the first ITS1-2 sequences in the GenBank database. For the remaining nine species, such sequences were already present in the database and showed a high level of identity $(>98 \%$ for seven species; $91.2 \%$ and $93.5 \%$ for Tripogon jacquemontii and Urochloa ramosa, respectively) with our newly contributed data.

\subsection{Number of Pollen Grains per Anther}

The mean number of pollen grains per anther varied between 106 in Digitaria stricta (India) and 5495 in Arrhenatherum elatius (Russia, Moscow) (Table 2, Figure 1). Differences 
between species of the same genus were revealed in Poa, Digitaria, Chloris and Urochloa. In the cases of Chloris (C. barbata and C. virgata), Digitaria (D. ciliaris, D. stricta and D. sanguinalis) and Urochloa (U. ramosa and U. panicoides), pollen production differed with high levels of significance (Tukey's HSD test; $p$-values $<<0.001$ ). Differences between the three studied species of Poa (P. annua, P. pratensis and P. trivialis) were less significant (Tukey's HSD test; $p$-values $<0.01)$. Pollen production per anther was almost the same in Setaria intermedia and S. pumila, despite the fact that studied samples were collected in different climatic zones. Lolium perenne and Festuca pratensis, two species traditionally classified in different genera, but currently placed in Lolium sensu lato [9], were close in pollen production per anther. Pollen production per anther of all of the annual species sampled here was significantly lower compared with that of perennial species ( $t$-test; $p$-value $<<0.001)$. For the perennial species (Calamagrostis epigeios, Dactylis glomerata, Elymus repens, Lolium perenne, Phleum pratense, Poa trivialis) sampled in two locations within the same climatic zone (Moscow and Ryazan), no significant difference in pollen production per anther was observed between the two localities (Tukey's HSD test; $p$-values > 0.05; Figure 2). We also found no difference in pollen production between male and bisexual flowers of Arrhenatherum elatius ( $t$-test; $p$-value $>0.05)$; therefore, in subsequent analyses, we used our measurements of this species as a single dataset.

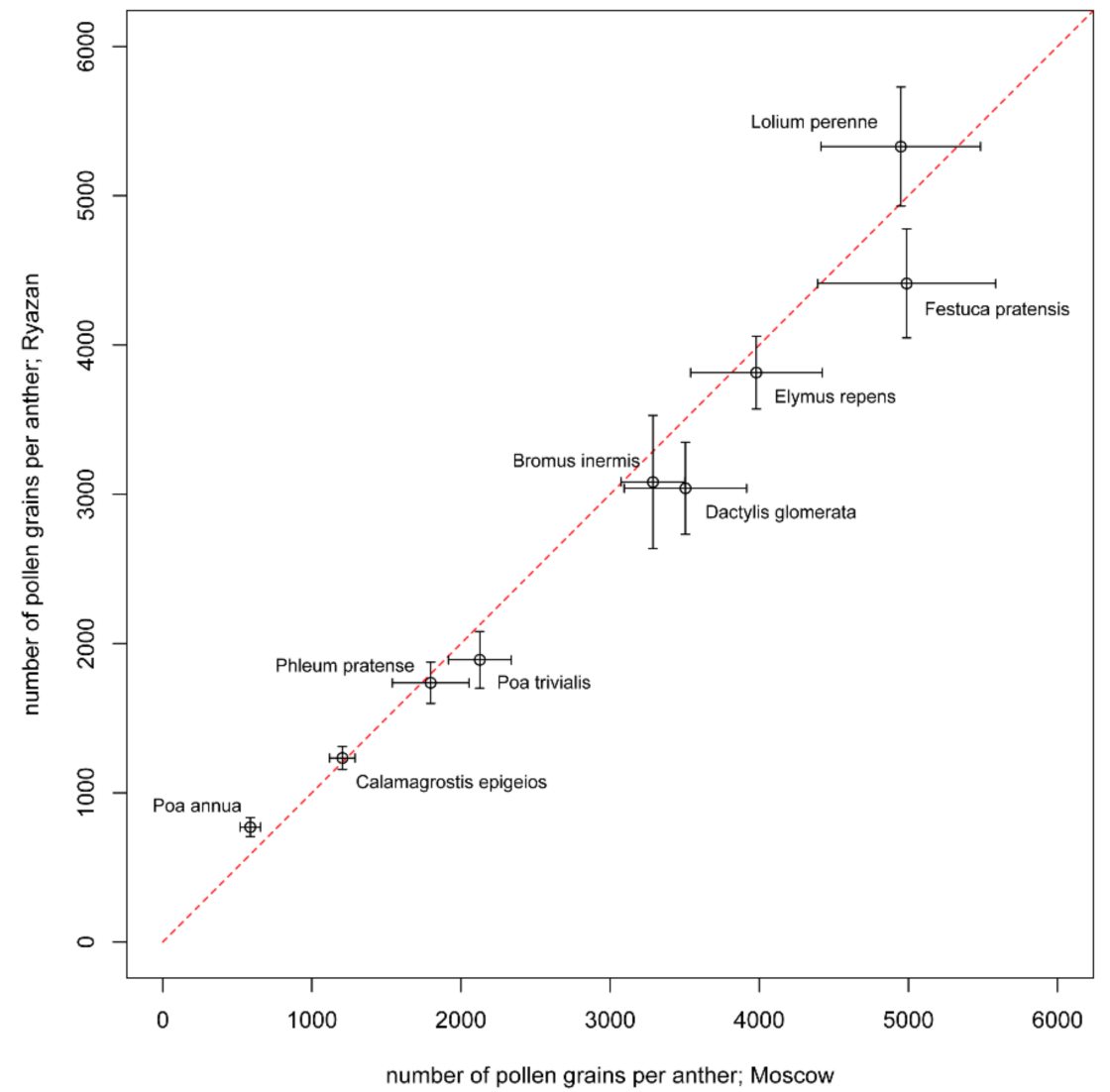

Figure 2. Comparison of samples from Moscow and Ryazan of studied species in terms of pollen production per anther. Mean values and their 95\% confidence intervals are shown. The red line indicates equal values in both populations. 
Table 2. Pollen production, anther length and diameter of pollen grains of studied species. Sampling location: I, India, R, Ryazan, M, Moscow. Data are shown as mean value $\pm 95 \%$ confidence interval (coefficient of variation, $\%$ ).

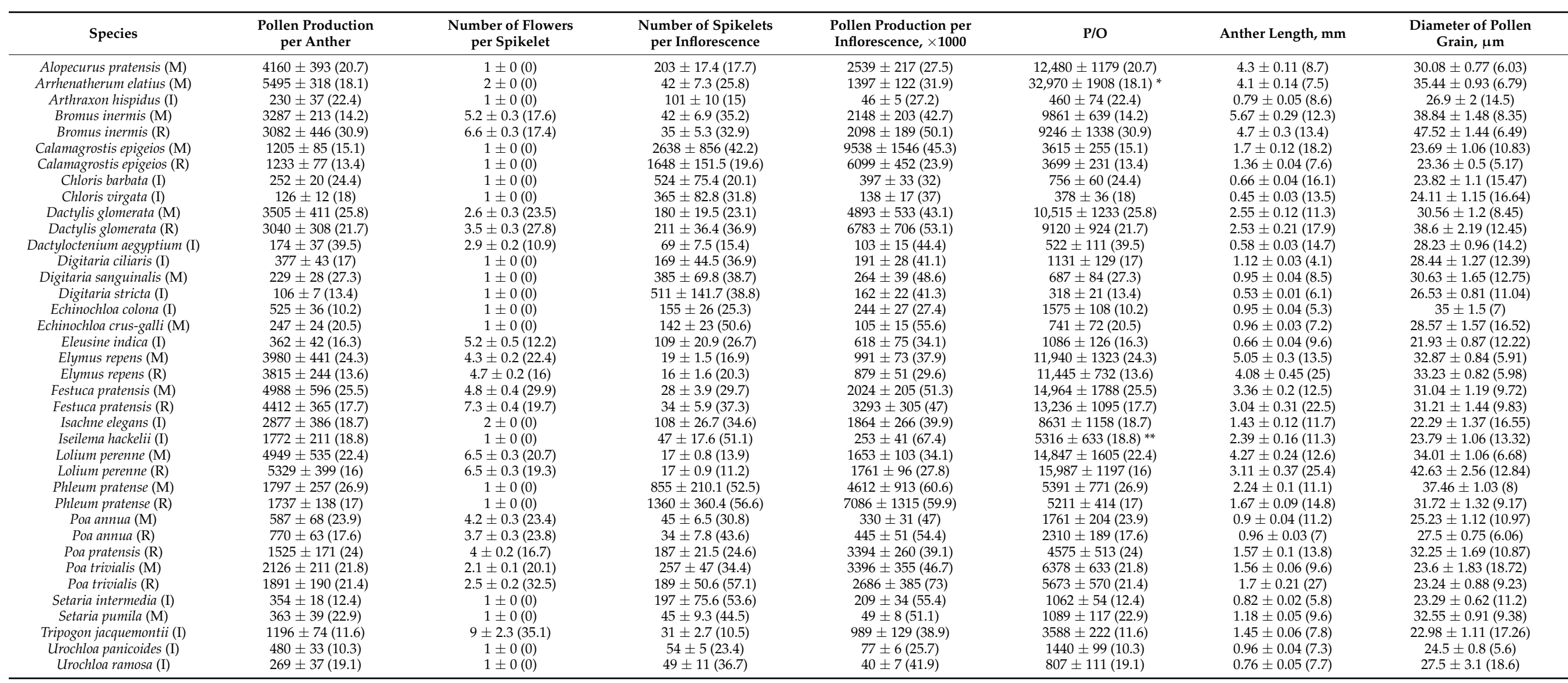

${ }^{*} \mathrm{P} / \mathrm{O}$ ratio of Arrhenatherum elatius was calculated for a spikelet consisting of one bisexual and one male flower. ${ }^{* *} \mathrm{P} / \mathrm{O}$ value of Iseilema hackelii was calculated for a group of spikelets consisting of several male and one female spikelet. 


\subsection{Pollen Production per Inflorescence}

The number of fertile flowers per spikelet was constant in 17 species, i.e., one or (Arrhenatherum elatius) two. Among other species, the mean number of flowers per spikelet varied from 2.1 (Poa trivialis) to 9 (Tripogon jacquemontii). This parameter was rather stable, with a coefficient of variation not exceeding 35\% (Tripogon jacquemontii). Most annuals examined here had spikelets with one flower; the exceptions were Eleusine indica and Poa annua, with the latter species being only a facultatively annual plant. The number of spikelets per inflorescence, in contrast, was the most variable parameter. The mean values ranged from 16 (Elymus repens, Ryazan) to 2638 (Calamagrostis epigeios, Moscow), with the coefficient of variation ranging from $11-14 \%$ (Lolium perenne) to $52-57 \%$ (Phleum pratense). A wide range of variability was typical for both annual and perennial species.

Pollen production per inflorescence varied between genera, between species within the same genus and between different samples of a species (Figure 3). The means ranged from c. 48,000 for Setaria pumila to c. 9,500,000 for Calamagrostis epigeios. The pollen production of the obligately annual species sampled here was significantly lower compared with that of perennial species ( $t$-test; $p$-value $<<0.001$; Poa annua was not included in this analysis, as it cannot be precisely identified as either annual or perennial species) and varied from c. 40,000 (Urochloa ramosa) to c. 617,000 (Eleusine indica). Pollen production per inflorescence in the perennial species Iseilema hackelii was within the range of variation found among annual species sampled here. The mean pollen production of the other perennials studied here was higher than that in annuals, though the figures found for Elymus repens and Tripogon jacquemontii approached those of the most productive annual Eleusine indica. The pollen production per inflorescence of Роа аппиа fell into the range observed for obligate annual species.

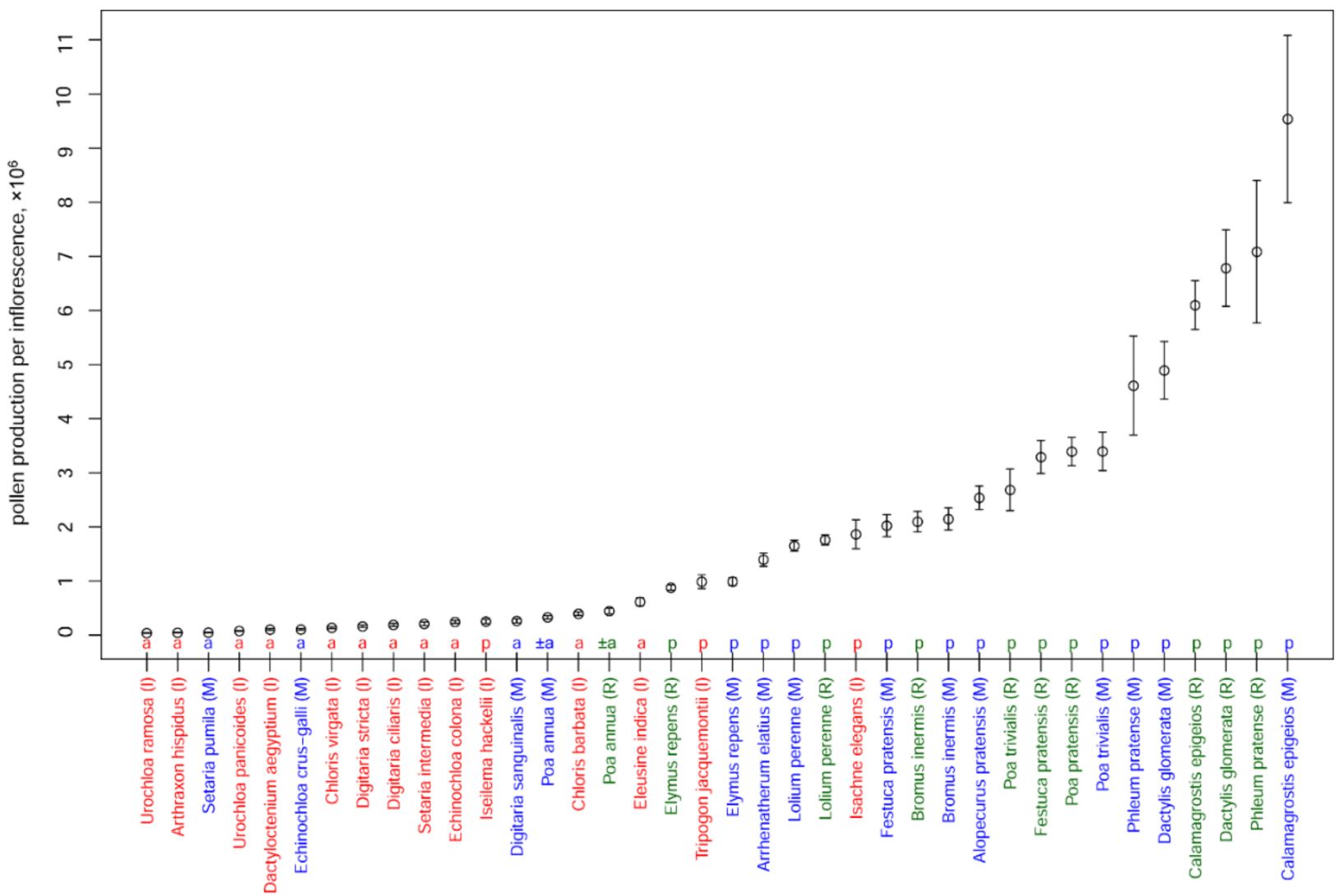

Figure 3. Pollen production per inflorescence in studied species; $n=$ the number of inflorescences examined in each species. Mean values and their $95 \%$ confidence intervals are shown. a, obligate annual; p, perennial. Colors indicate samples from different regions: red (I), India; green (R), Ryazan; blue (M), Moscow. 
In perennial species, we found a significant but not strong negative correlation between the number of spikelets per inflorescence and pollen production per anther (Spearman's rho $=-0.529 ; p$-value $<0.05)$, i.e., species with a low amount of pollen in their anthers tended to have lots of spikelets in their inflorescences.

Variability of pollen production per inflorescence within a genus was studied for Chloris, Digitaria, Setaria and Poa. The most significant differences were in Poa between P. annua and obligately perennial species. The pollen production of the obligately perennial species was 7-8 times higher than in P. annua. Chloris barbata and C. virgata differed in pollen production by 2.9 times, Setaria intermedia and S. pumila-by 4.3 times. The pollen production of the two Indian species of Digitaria was very similar, and 1.3-1.6 times lower than that of $D$. sanguinalis from Russia.

The pollen production per inflorescence of Calamagrostis epigeios, Dactylis glomerata, Phleum pratense, Poa trivialis and Festuca pratensis differed between samples: for Calamagrostis epigeios and Poa trivialis, the values were higher in Moscow, while the others showed higher values in Ryazan (Figure 4; $t$-test, all the $p$-values $<0.05$ ). For Bromus inermis, Poa annua, Elymus repens and Lolium perenne, no significant difference in pollen production per inflorescence between the two Russian locations was observed.

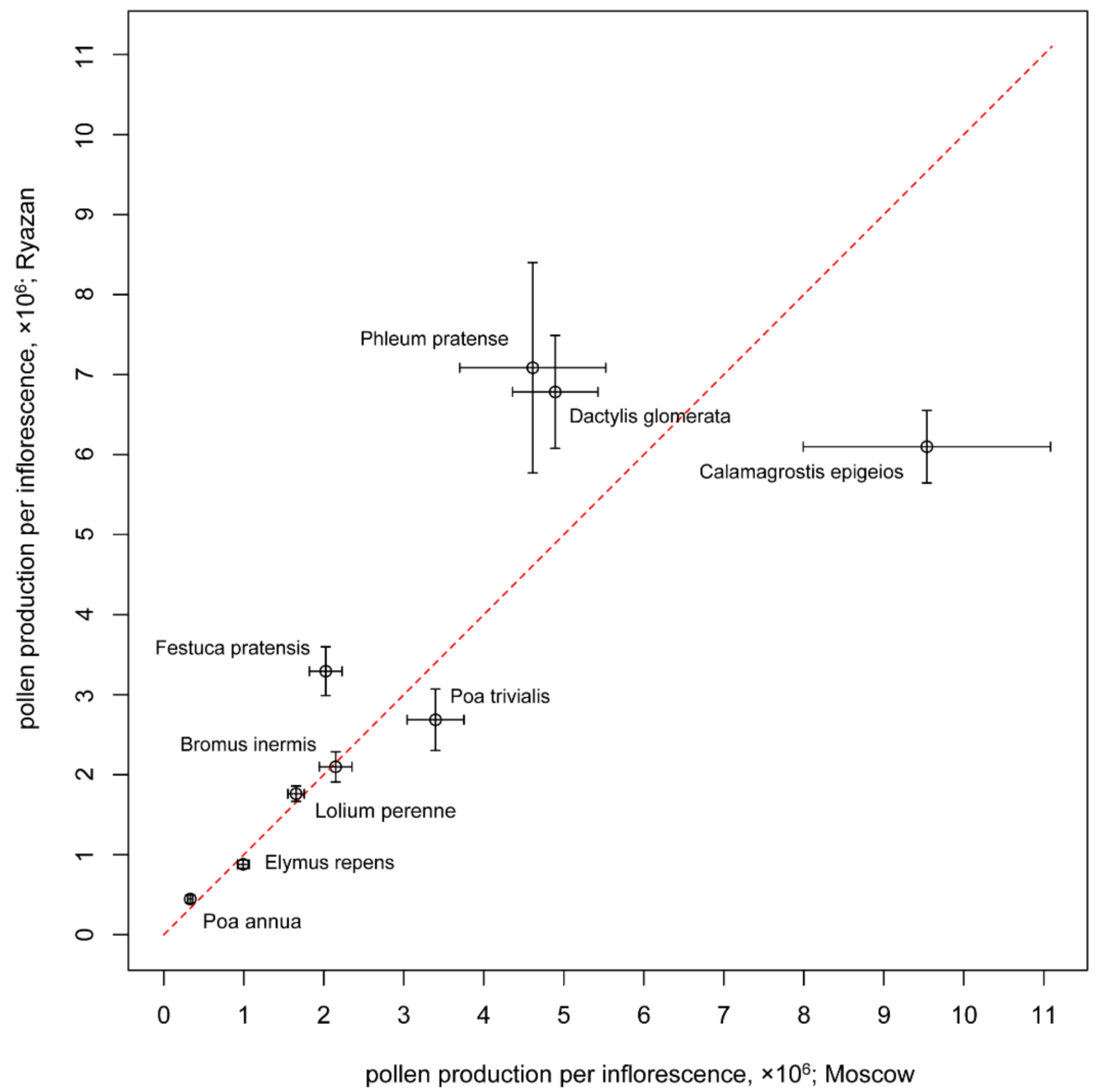

Figure 4. Comparison of samples from Moscow and Ryazan of studied species in terms of pollen production per inflorescence. Mean values and their $95 \%$ confidence intervals are shown. The red line indicates an equal value in both locations.

\subsection{Anther Length, Diameter of Pollen Grains and Pollen Production per Anther}

No strong correlation was found between pollen grain size and pollen production per anther in our sample set. A strong and significant positive correlation (Pearson's 
$r=0.857 ; p$-value $<<0.001)$ was observed between the anther length and the pollen production per anther (Figure 5). Our equation of linear regression was the following: pollen production $=1024.4 \times$ length (the intercept did not significantly differ from 0 ; the coefficient was significant at $p$-value $<<0.001 ; R^{2}=0.735$ ). This tendency was clear for both regions (Russia and India) and for plants of both life forms (annual and perennial; $r$ and $p$-values not shown). We also revealed a positive correlation between the diameter of pollen grain and anther length (Pearson's $r=0.652 ; p$-value $<0.01$ ), which means that longer anthers tend to develop larger pollen grains. The pollen grains of annual species usually did not exceed $30 \mathrm{~mm}$ in diameter, with the exception of Setaria pumila and Digitaria sanguinalis, although some perennial plants also had pollen grains of this size (Isachne elegans, Iseilema hackelii, Tripogon jacquemonti, Calamagrostis epigeios, Poa trivialis, Alopecurus pratensis). Pollen grains with the biggest diameter belonged to perennial plants (Bromus, Lolium), but the size of pollen differed considerably among different samples of the same species (in Bromus, Dactylis, Lolium, Phleum; Table 2).

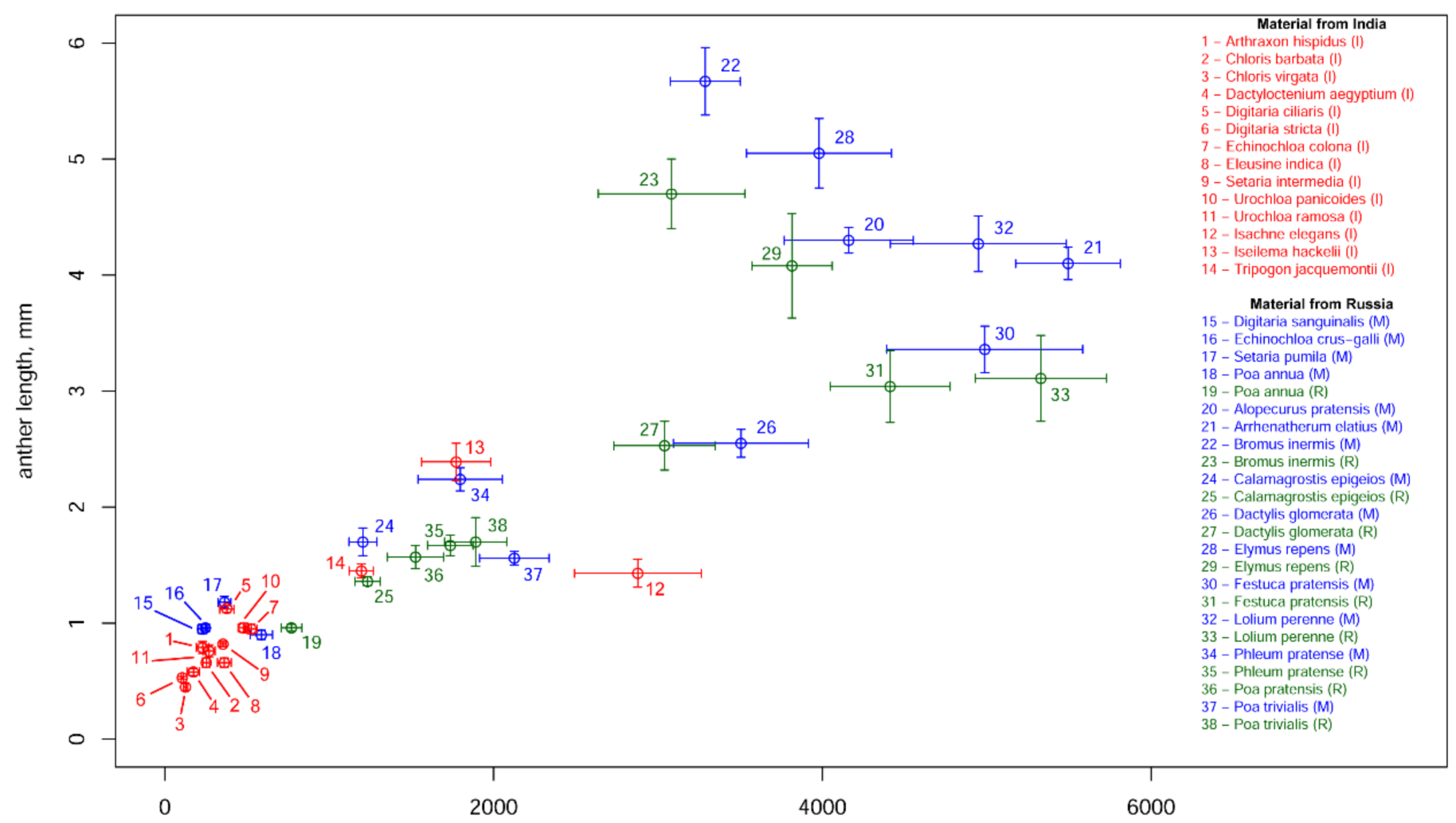

Figure 5. Scatter plot of pollen production per anther vs. anther length for studied species. Mean values and their 95\% confidence intervals are shown. Pearson's $r$ between variables is 0.857 ( $p$-value $<<0.001)$; equation of linear regression is: pollen production $=1024.4 \times$ length. I, India (red); R, Ryazan (green); M, Moscow (blue).

\subsection{Pollen/Ovule Ratio}

Grass flowers have no more than one ovule, so when all flowers are uniform and bisexual, the pollen production per flower is equal to $\mathrm{P} / \mathrm{O}$ ratio, a parameter that shows the ratio between pollen production and the number of ovules. The $\mathrm{P} / \mathrm{O}$ ratios of all obligate annuals sampled here were lower than those of facultative annuals and perennials (Figure 6). The $\mathrm{P} / \mathrm{O}$ ratios calculated for the two samples of the facultatively annual species Poa annua slightly exceeded those of the obligate annuals (Figure 6). The highest $\mathrm{P} / \mathrm{O}$ ratio was found in Arrenatherum elatius, the only species possessing both male and bisexual flowers sampled in the present study. When more than one species per genus were sampled, their $\mathrm{P} / \mathrm{O}$ ratios differed considerably (in Poa, Digitaria, Chloris, Echinochloa, Urochloa). 


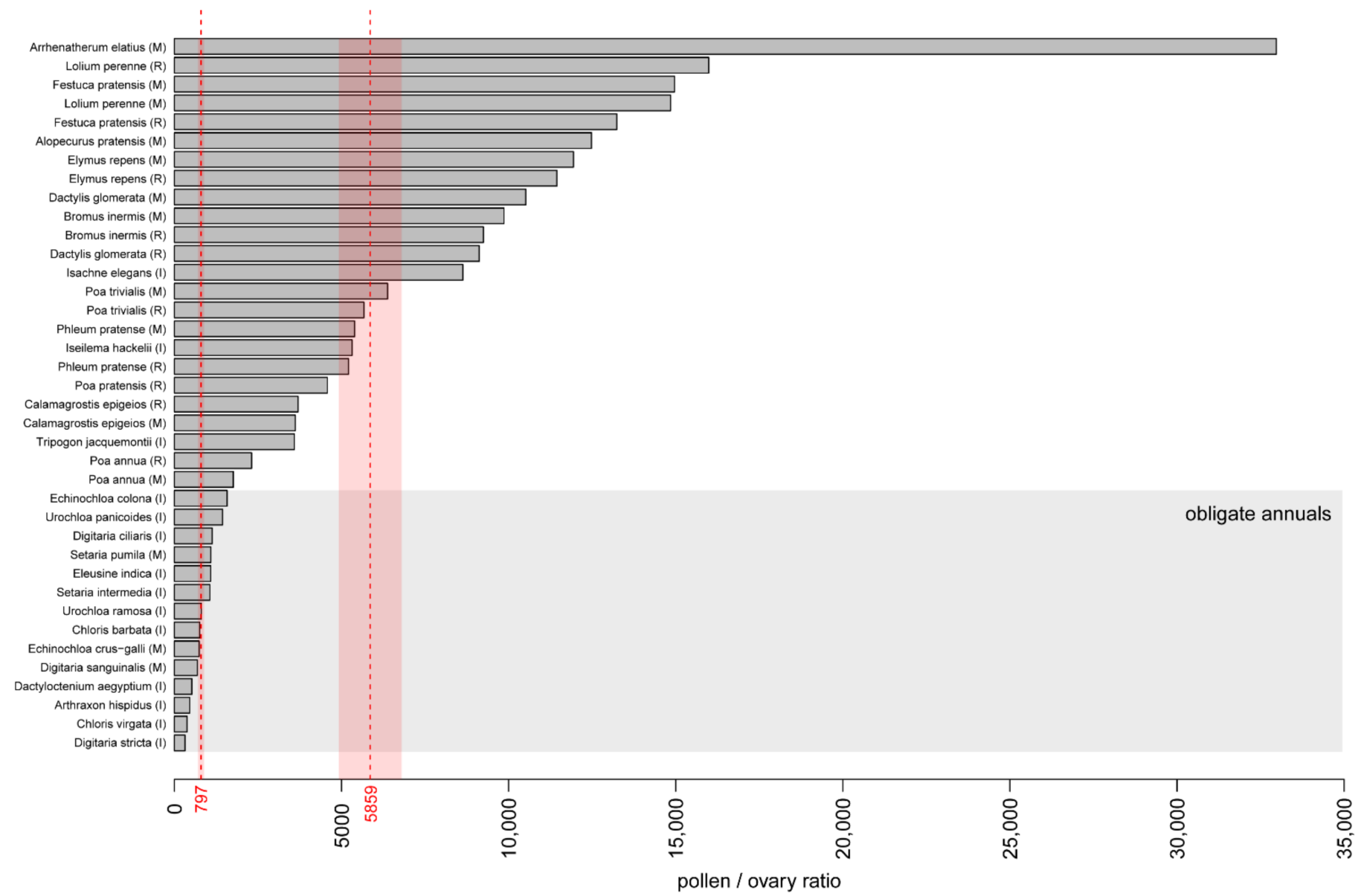

Figure 6. Pollen/ovule ratio of studied species. In the dataset of Cruden [30] who studied a range of angiosperm species, mean $\mathrm{P} / \mathrm{O}$ ratio of facultatively xenogamous species was $797 \pm 88$ and that of obligate xenogamy was $5859 \pm 936$. These values are indicated here in red.

\section{Discussion}

Except for some cleistogamous species, anemophily is the main pollination strategy in the family Poaceae. It is generally assumed that pollen production per anther (and flower) is controlled by genotype and is largely fixed [31]. Our study supports this hypothesis, as the pollen production per anther was one of the most stable parameters. Its coefficient of variation did not exceed 39\% and, in most species, was less than $25 \%$. Twelve of the species studied here have been previously studied by other authors (Table 3).

In some cases, the recorded differences in mean pollen production per flower between the present study and literature were insignificant, as the literature values were within the 95\% confidence interval of the mean values inferred in our study (Lolium perenne, Eleusine indica, Dactyloctenium aegyptium, Digitaria ciliaris, two out of four literature records for Dactylis glomerata). In other instances (e.g., Festuca pratensis), literature data showed more than twofold difference from our observations (Table 3). Possible explanations of this disagreement may be the influence of local climatic conditions [61], different physiological status of a plant [62], differences in pollen production among varieties of a species [62] or the lack of a uniform pollen counting method. A case study of five species of Bromus revealed differences in anther length (and thus pollen production) between the lower and upper flowers of a spikelet [34]. In B. inermis, pollen production per anther was decreased to $77 \%$ by defoliation and increased to $132 \%$ in shoots that grew on thatching ant (Formica obscuripes) mounds [34]. Notably, in no case in the present study did we observe a twofold difference between Moscow and Ryazan samples of the same species. Similarly, a twofold level of difference was not found in the case study of McKone [34]. 
Table 3. Comparison of mean pollen production per flower according to the present study and literature. Values in bold are within the $95 \%$ confidence interval of the means obtained in our study.

\begin{tabular}{|c|c|c|c|c|c|c|c|c|c|c|}
\hline & $\begin{array}{l}\text { This Study: } \\
\text { I, India; } \\
\text { M, Moscow; } \\
\text { R, Ryazan }\end{array}$ & $\begin{array}{c}\text { Prieto- } \\
\text { Baena et al. } \\
\text { [27] }\end{array}$ & $\begin{array}{l}\text { Aboulaich } \\
\text { et al. [28] }\end{array}$ & $\begin{array}{c}\text { Kaybeleva, } \\
\text { Yudakova } \\
\text { [32] }\end{array}$ & $\begin{array}{l}\text { Tormo- } \\
\text { Molina } \\
\text { et al. [42] }\end{array}$ & $\begin{array}{c}\text { Bai, Reddy } \\
\text { [33] }\end{array}$ & $\begin{array}{c}\text { Smart et al. } \\
{[40]}\end{array}$ & $\begin{array}{c}\text { Subba } \\
\text { Reddi, } \\
\text { Reddi [31] }\end{array}$ & $\begin{array}{l}\text { Cruden } \\
\text { [30] }\end{array}$ & $\begin{array}{l}\text { McKone } \\
\text { [34] }\end{array}$ \\
\hline $\begin{array}{l}\text { Bromus } \\
\text { inermis }\end{array}$ & $\begin{array}{l}9861(\mathrm{M}) \\
9246(\mathrm{R})\end{array}$ & & & & & & & & & 11,913 \\
\hline $\begin{array}{l}\text { Chloris } \\
\text { barbata }\end{array}$ & 756 (I) & & & & & 837 & & 945 & & \\
\hline $\begin{array}{c}\text { Dactylis } \\
\text { glomerata }\end{array}$ & $\begin{array}{c}10,515(\mathrm{M}) \\
9120(\mathrm{R})\end{array}$ & 10,425 & 6429 & 9240 & 5431 & & 3900 & & & \\
\hline $\begin{array}{l}\text { Dactyloctenium } \\
\text { aegyptium }\end{array}$ & $522(\mathrm{I})$ & & & & & & & 555 & & \\
\hline $\begin{array}{l}\text { Digitaria } \\
\text { ciliaris }\end{array}$ & 1131 (I) & & & & & & & 1125 & & \\
\hline $\begin{array}{c}\text { Digitaria } \\
\text { sanguinalis }\end{array}$ & 687 (I) & & & & & & & & 1234 & \\
\hline $\begin{array}{l}\text { Echinochloa } \\
\text { crus-gali }\end{array}$ & 741 (I) & & & & & & & & 1267 & \\
\hline $\begin{array}{l}\text { Eleusine } \\
\text { indica }\end{array}$ & 1086 (I) & & & & & & & 810 & 1111 & \\
\hline $\begin{array}{l}\text { Elymus } \\
\text { repens }\end{array}$ & $\begin{array}{l}11,940(\mathrm{M}) \\
11,445(\mathrm{R})\end{array}$ & 16,230 & & & & & & & & \\
\hline $\begin{array}{c}\text { Festuca } \\
\text { pratensis }\end{array}$ & $\begin{array}{l}14,964(\mathrm{M}) \\
13,236(\mathrm{R})\end{array}$ & & & 5151 & & & & & & \\
\hline $\begin{array}{l}\text { Lolium } \\
\text { perenne }\end{array}$ & $\begin{array}{l}14,847(\mathrm{M}) \\
15,987(\mathrm{R})\end{array}$ & & & & & & 16,200 & & & \\
\hline Роа аппиа & $\begin{array}{l}1761(\mathrm{M}) \\
2310(\mathrm{R})\end{array}$ & 1022 & 1216 & 5523 & & & & & & \\
\hline $\begin{array}{c}\text { Poa } \\
\text { pratensis }\end{array}$ & 4575 (R) & & & 3735 & & & & & & \\
\hline Poa trivialis & 6378 (M) 5673 (R) & & 3386 & & & & & & & \\
\hline
\end{tabular}

Possible differences in methods of counting pollen grains (and their preciseness) increases the significance of studies that include multiple grass species from different geographical regions and more than one sample per species. The present study provides a large dataset in this respect. Prieto-Baena et al. [26] presented highly important data on as many as 38 grass species from the city of Córdoba (Spain), but they did not compare samples of the same species from different localities and did not provide data on variations in pollen production per inflorescence, as we have done.

The $\mathrm{P} / \mathrm{O}$ ratio is a conservative indicator of breeding systems and reflects their efficiency, i.e., the more efficient the transfer of pollen, the lower the $\mathrm{P} / \mathrm{O}$ ratio $[30,63]$. This ratio usually increases in the direction of cleistogamy $\rightarrow$ obligate autogamy $\rightarrow$ facultative autogamy $\rightarrow$ facultative xenogamy $\rightarrow$ obligate xenogamy. In our study, the $\mathrm{P} / \mathrm{O}$ ratios of obligate annuals varied from 318 to 1131 (Figure 6). These data suggest that the annual species studied here are most likely facultatively xenogamous. Indeed, in the dataset published by Cruden [30], who studied a range of angiosperm species, the mean $\mathrm{P} / \mathrm{O}$ ratio of facultatively xenogamous species was $797 \pm 88$, whereas the mean values for facultative autogamy and obligate xenogamy were $169 \pm 22$ and $5859 \pm 936$, respectively. The differences in $\mathrm{P} / \mathrm{O}$ values between species of the same genus revealed in the present study (Chloris virgata $\mathrm{P} / \mathrm{O}=379$ and C. barbata $\mathrm{P} / \mathrm{O}=757 ;$ Digitaria stricta $\mathrm{P} / \mathrm{O}=318$ and D. ciliaris $\mathrm{P} / \mathrm{O}=1132$ ) may indicate different reproductive strategies of the species. The species of Digitaria studied here have similar pollen production per inflorescence, but differ significantly in the length of the anthers and the number of spikelets in the inflorescence. The difference in the $\mathrm{P} / \mathrm{O}$ values of closely related species may be associated with a change in the reproductive strategy depending on environmental conditions [30]. The $\mathrm{P} / \mathrm{O}$ values for Digitaria sanguinalis and Echinocloa crus-gali published by Cruden [30] were nearly two times higher than our results for the same species. Cruden [30] observed "dramatic intraspecific 
variations" of $\mathrm{P} / \mathrm{O}$ for some eudicot species, which, in all cases, was related to intraspecific differences in flower size. This also can be attributed to different habitat conditions and the degree of disturbance therein [30]. We believe that this disagreement may relate to different sampling time (midgrowing season or its start/end, when the meteorological conditions can be unfavorable). In the obligately perennial species sampled here, $\mathrm{P} / \mathrm{O}$ values varied from 3587 (Tripogon jacquemontii) to 32,970 (Arrhenatherum elatius), which, based on the figures provided by Cruden [30], suggest the occurrence of obligate xenogamy.

It is necessary to note that apart from the $\mathrm{P} / \mathrm{O}$ ratio, another parameter could be useful in future studies of reproductive biology. Namely, it is reasonable to divide the pollen production by the total seed production. Detailed studies by Smith [64] based on native and exotic grasses of Pacific Northwest of the United States revealed great differences among grass species in terms of the percentage of seed set per flower. Among the species sampled here, the clonal perennial grass Calamagrostis epigeios is known to show a variable and generally low percentage of seed set per flower. The percentage of well-developed fruits ranged from c. $5 \%$ to c. $43 \%$ in populations examined in Germany $[65,66]$. Invasive North American populations of C. epigeios mostly do not produce seeds at all [67]. Notably, in the present study, pollen production per flower and the $\mathrm{P} / \mathrm{O}$ ratio revealed C. epigeios to be among the lowest among perennial species sampled here. In contrast, the pollen production per inflorescence found in the present study for $C$. epigeios showed the highest figures among the grass species sampled here. We believe than when all data have been recalculated to Pollen/Seed ratios, the figures for C. epigeios should better fit the typical values of xenogamous perennial grasses. Therefore, we highlight a need for detailed studies of reproductive biology in grasses that include both pollen and seed production.

Apart from Calamagrostis epigeios, there is another perennial grass in our dataset with a remarkably low $\mathrm{P} / \mathrm{O}$ ratio, Tripogon jacquemontii. We found no detailed observations regarding the reproductive biology of T. jacquemontii, but according to Thoiba and Pradeep [68], some Indian species of Tripogon are characterized by very low seed setting. In addition, Tripogon jacquemontii is remarkable in its ecology. This is apparently the only desiccationtolerant grass sampled here [69].

Among the grass species studied here, the highest $\mathrm{P} / \mathrm{O}$ ratio was found in Arrhenatherum elatius. This was the only species in our dataset that possesses male and bisexual flowers. The occurrence of male flowers should be viewed as an adaptation to crosspollination, which likely explains the increased $\mathrm{P} / \mathrm{O}$ ratio. Our $\mathrm{P} / \mathrm{O}$ ratio count for $A$. elatius $(32,970)$ was close to an earlier count $(37,124)$ by Pohl $(1937$, cited after [63]). Based on data from Prieto-Baena et al. [27], another species of the genus, Arrhenatherum album, has a twofold higher $\mathrm{P} / \mathrm{O}$ ratio than $A$. elatius.

According to Baumann et al. [70], all four species with the highest $\mathrm{P} / \mathrm{O}$ ratios found in the present study (Arrhenatherum elatius, Lolium perenne, Festuca pratensis, Alopecurus pratensis) are likely self-incompatible. Data from Smith [64] allow us to add to this list Dactylis glomerata, Bromus inermis and Elymus repens. Therefore, all seven species with the highest $\mathrm{P} / \mathrm{O}$ ratios (Figure 6) are self-incompatible. Why then does Arrhenatherum elatius still have a much higher $\mathrm{P} / \mathrm{O}$ ratio than the six other species? An increased $\mathrm{P} / \mathrm{O}$ ratio could be expected in a species with pronounced clonal growth (so that the distance to another genotype may be increased), but A. elatius is not capable of a clonal growth [71] The high $\mathrm{P} / \mathrm{O}$ ratio of $A$. elatius relative to other self-incompatible species sampled here can be plausibly explained by differences in the percentage of seed set. The average number of developed seeds per flower was estimated as 0.399 in A. elatius, a figure approaching those for Dactylis glomerata (0.417), Bromus inermis (0.375), and Elymus repens (0.248) [64]. However, all Bromus, Elymus and Dactylis flowers are female-fertile, whereas every second flower is male in Arrhenatherum. Therefore, relative to female-fertile flowers, the average number of developed seeds is close to 0.8 in A. elatius. This much higher seed set percentage is most likely facilitated by the high $\mathrm{P} / \mathrm{O}$ ratio in $A$. elatius.

The example of Arrhenatherum shows that placing data in a broad context of reproductive biology is essential for interpreting pollen production in grasses, but currently available 
data in many instances remain insufficient for making such comparisons. As pointed out by Kellogg [9], given the ecological dominance of grasses, it is surprising how few studies have been undertaken on their breeding systems. Apparently, self-incompatibility is only rarely complete in grasses, though it is difficult to reject a hypothesis that the low levels of seed set still found in bagged plants of such species may be partly explained by apomixis [64]. Some grasses including $A$. elatius show certain genetically-determined infraspecific variations in their degree of self-incompatibility [64,71-73]. It will be interesting to learn whether genotypes that differ in degrees of self-incompatibility also differ in pollen production per anther. To our knowledge, such data are not available to date.

Pollen production per inflorescence is determined by a number of parameters, some of which are relatively stable (pollen production of an anther, number of stamens, number of flowers per spikelet), while others (number of spikelets per inflorescence) are more variable and seem to be, to a large extent, environmentally determined [27,28]. In some cases, lower production of pollen per anther (Calamagrostis) can be compensated for by larger numbers of spikelets per inflorescence, and vice versa, i.e., species with a lower number of flowers (Lolium) display very high pollen production per anther.

Our results support the hypothesis that pollen production per inflorescence differs significantly between annual and perennial species. The greater pollen production of perennial plants can be interpreted as a tendency to guarantee the cross-fertilization of species with self-incompatibility, which is typical for many perennial grasses [14,70] and plants from other angiosperm families [74-76]. Note that beyond the taxon sampling of the present study, there are self-incompatible species of annual grasses that predictably show high $\mathrm{P} / \mathrm{O}$ ratio values. Most remarkably, the $\mathrm{P} / \mathrm{O}$ ratio of the annual cereal crop rye (Secale cereale) is higher than those of any annual or perennial species sampled here, and indeed, higher than those of most other grasses examined to date [63]. P/O values greater than in Secale (c. 57,000) were only observed in Leymus chinenis (c. 80,000) and Pariana stenolemma (c. 300,000), with the latter being pollinated by beetles and flies [77]. One may speculate that the high $\mathrm{P} / \mathrm{O}$ ratio of rye is in part due to domestication, because it maximizes the seed set under the conditions of self-incompatibility.

Among perennial plants, the lowest pollen production per inflorescence was noted for Iseilema hackelii, a species with complex spikelet clusters of dimorphic spikelets. The taxonomy of Iseilema is complicate. We applied the nomenclature adopted by Chorghe and Tiwari [78]. In our material, each cluster consisted of four well-developed male spikelets forming an involucre, two central sterile pedicelled male spikelets (with reduced anthers or without them at all) and a central sessile female spikelet. According to the literature, the female-fertile spikelets of Iseilema are bisexual, while pedicelled male spikelets are fertile $[9,54,79,80]$. Future studies should pay more attention to the presence or absence of stamens in female-fertile spikelets of Iseilema, as literature data in this respect are obviously incomplete. The pollen production of Iseilema hackelii is comparable with that of Poa annua, an annual or short-living perennial species [81] studied here using material from Russia. The pollen production of other studied perennial species from India, i.e., Tripogon jacquemontii and Isachne elegans (the latter species is only facultatively perennial [54]), was found to exceed those of obligatory annual species by 2-4 times, approaching those of perennial species from Russia (Bromus, Elymus, Lolium), which confirms the hypothesis of higher pollen production by perennial grasses. The two facultatively annual species studied here (Poa annua and Isachne elegans) surpassed all obligate annuals included in this study in terms of their pollen production per inflorescence.

Unlike Friedman and Harder [52], we found no strong correlation between pollen production and the size of pollen grains, but demonstrated a significant correlation between pollen production per anther and anther length. We believe that this provides an instrument for comparisons of the pollen production of grass species and estimates of pollen production in plant communities without requiring time-consuming calculations of pollen grains in anthers under a microscope. Instead, rough estimates may be made using much simpler measurements of anther length. Moreover, as anther length is so frequently used as a 
key characteristic in grass taxonomy, measurements are, in many cases, already available in literature. Our data support earlier studies that documented correlations between anther length and pollen production in particular taxa of grasses [36,37,39]. McKone [34] demonstrated that anther length is an excellent predictor of pollen production in Bromus $\left(R^{2}=0.96\right)$. The dataset generated in the present study provided a lower value of coefficient of determination $\left(R^{2}=0.73\right)$. However, given the fact that we analyzed a set of distantlyrelated grass species belonging to different subfamilies and adapted to different ecological conditions, we consider the regression found in the present study to be conclusive and useful. The regression coefficients revealed for such varieties of wheat as "Gaby" (1050) and "Orca" (1072) by De Vries [39] were close to those found in the present study (1024). As McKone [34] provided coefficients of regression between anther length and volume of pollen instead of number of pollen grains, it is impossible to compare that result with ours.

The size of pollen grains is usually considered as a fairly stable feature. Our results show that the diameter of the pollen grains of Bromus inermis, Dactylis glomerata, Lolium perenne, Phleum pratense from different populations can differ considerably. We presume this to be related to different environmental conditions, primarily concerning mineral nutrition [82,83], even though the genetic heterogeneity of plant material cannot be excluded, especially in polyploid complexes. Such a wide range of variation should be taken into account when pollen size is used as an indicator of polyploidy or taxonomic character. In each specific case, such a relationship must be validated independently. For example, two samples of a taxonomically - and cytologically - homogenous species, i.e., Aponogeton satarensis (Aponogetonaceae), revealed ca. 1.4-times difference in mean pollen grain size [84].

\section{Conclusions}

Among the parameters that determine pollen production per inflorescence, pollen production per anther and the number of flowers per spikelet were found to be more stable than the number of spikelets per inflorescence, which is highly variable in nature. In some cases, lower production of pollen per anther can be compensated for by a larger number of spikelets per inflorescence, and vice versa, i.e., species with fewer flowers have very high pollen production per anther. The values of pollen production per flower in our study only partly agreed with previously published data. This disagreement may have been due to the influence of local climatic conditions, the different physiological status of various plants, differences in pollen production among genotypes or the lack of a uniform pollen counting method.

Our results support the hypotheses that pollen production per inflorescence differs significantly between annual and perennial species. The greater pollen production of perennial plants can be interpreted as a tendency to guarantee the cross-fertilization of species with self-incompatibility. In our study, the $\mathrm{P} / \mathrm{O}$ values allowed us to suggest facultative xenogamy for all annual species and obligate xenogamy for most perennial species. However, self-incompatible annuals with high $\mathrm{P} / \mathrm{O}$ values do exist among grasses not included in our dataset.

There is a correlation between pollen production per anther and anther length that allows rough comparisons to be made of the pollen production of grass species, and estimates to be made of pollen production in plant communities. This work provides new data that must be taken into account in phenological studies and aerobiological analyses.

Further research should aim to achieve a better understanding of the reproductive biology of individual grass species and biological interpretation of quantitative characteristics, such as pollen production and pollen/ovule ratio. We suggest the use of another parameter, namely, the pollen/seed ratio, that could be a finer indicator of the pollination strategies of various plant species. There is a wide field of research in refinement of biological interpretation of pollen production. For example, it is well-known that grass anthesis is normally restricted to a short period each day. In theory, the shorter the period of anthesis, the lower the $\mathrm{P} / \mathrm{O}$ or $\mathrm{P} / \mathrm{S}$ ratio, because a higher pollen concentration in air can be achieved. 
This hypothesis requires experimental testing. One would also expect a link to be observed between characteristics related to effective pollen dispersal (viability of pollen, its weight and size, inflorescene position above the substrate) and pollen production. Finally, much more detailed knowledge of patterns of incompatibility in various grass species is required, for example, to figure out to what extent plants with nonidentical genotypes existing in the same population are partly incompatible with each other [9].

Author Contributions: Conceptualization, E.S. and D.S.; Funding acquisition, E.S. and D.S.; Investigation, E.S., Y.K.-G., S.R.Y., Y.S. and V.K.; Methodology, E.S.; Supervision, E.S. and D.S.; Visualization, Y.K.-G.; Writing—original draft, E.S., Y.K.-G. and D.S.; Writing-review \& editing, S.R.Y. All authors have read and agreed to the published version of the manuscript.

Funding: This research was funded by Russian Foundation for Basic Research, project 19-05-50035 (samples from Russia) and Russian Science Foundation, project 19-14-00055 (samples from India).

Institutional Review Board Statement: Not applicable.

Informed Consent Statement: Not applicable.

Data Availability Statement: Data is contained within the article.

Acknowledgments: We are grateful to three anonymous Reviewers for helpful suggestions, to Sergei Majorov for discussion on Russian grasses and for Manoj Lekhak, Maxim Nuraliev, Anna Platonova and Margarita Remizowa for help during field work in India.

Conflicts of Interest: The authors declare no conflict of interest.

\section{References}

1. Soreng, R.J.; Peterson, P.M.; Romaschenko, K.; Davidse, G.; Teisher, J.K.; Clark, L.G.; Barberá, P.; Gillespie, L.J.; Zuloaga, F.O. A worldwide phylogenetic classification of the Poaceae (Gramineae) II: An update and a comparison of two 2015 classifications. J. Syst. Evol. 2017, 55, 259-290. [CrossRef]

2. McKevith, B. Nutritional aspects of cereals. Nutr. Bull. 2004, 29, 111-142. [CrossRef]

3. Laskowski, W.; Górska-Warsewicz, H.; Rejman, K.; Czeczotko, M.; Zwolińska, J. How important are cereals and cereal products in the average polish diet? Nutrients 2019, 11, 679. [CrossRef]

4. Watson, L. The grass family, Poaceae. In Reproductive Versatility in the Grasses; Cambridge University Press: Cambridge, UK, 1990; pp. 1-31.

5. D'Amato, G.; Cecchi, L.; Bonini, S.; Nunes, C.; Annesi-Maesano, I.; Behrendt, H.; Liccardi, G.; Popov, T.; Van Cauwenberge, P. Allergenic pollen and pollen allergy in Europe. Allergy 2007, 62, 976-990. [CrossRef] [PubMed]

6. García-Mozo, H. Poaceae pollen as the leading aeroallergen worldwide: A review. Allergy 2017, 72, 1849-1858. [CrossRef]

7. Andersson, K.; Lidholm, J. Characteristics and immunobiology of grass pollen allergens. Int. Arch. Allergy Immunol. 2003, 130, 87-107. [CrossRef]

8. Linder, H.P.; Rudall, P.J. Evolutionary history of Poales. Annu. Rev. Ecol. Evol. Syst. 2005, 36, 107-124. [CrossRef]

9. Kellogg, E.A. Poaceae. In The Families and Genera of Vascular Plants; Springer: Berlin/Heidelberg, Germany, 2015; Volume XIII, pp. 1-416.

10. Adams, D.E.; Perkins, W.E.; Estes, J.R. Pollination systems in Paspalum dilatatum Poir. (Poaceae): An example of insect pollination in a temperate grass. Am. J. Bot. 1981, 68, 389-394. [CrossRef]

11. Campbell, C.S.; Quinn, J.A.; Cheplick, G.P.; Bell, T.J. Cleistogamy in grasses. Annu. Rev. Ecol. Syst. 1983, 14, 411-441. [CrossRef]

12. Chhabra, A.K.; Sethi, S.K. Inheritance of cleistogamic flowering in durum wheat (Triticum durum). Euphytica 1991, 55, 147-150. [CrossRef]

13. Ueno, K.; Itoh, H. Cleistogamy in wheat: Genetic control and the effect of environmental conditions. Cereal Res. Commun. 1997, 25, 185-189. [CrossRef]

14. Connor, H.E. Breeding systems in the grasses: A survey. N. Z. J. Bot. 1979, 17, 547-574. [CrossRef]

15. Heslop-Harrison, J. The function of the glume pit and the control of cleistogamy in Bothriochloa decipiens (Hack.) C.E. Hubbard. Phytomorphology 1961, 11, 378-383.

16. Knox, R.B.; Heslop-Harrison, J. Experimental control of aposporous apomixis in a grass of the Andropogoneae. Bot. Not. 1963, $116,127141$.

17. Quarin, C.L. Seasonal changes in the incidence of apomixis of diploid, triploid, and tetraploid plants of Paspalum cromyorrhizon. Euphytica 1986, 35, 515-522. [CrossRef]

18. Soderstrom, T.R.; Calderón, C.E. Insect pollination in tropical rain forest grasses. Biotropica 1971, 3, 1-16. [CrossRef]

19. Janzen, D.H. Why bamboos wait so long to flower. Annu. Rev. Ecol. Syst. 1976, 7, 347-391. [CrossRef] 
20. Jackson, G.C.; Woodbury, R.O. Host plants of the carpenter bee, Xylocopa brasilianorum L. (Hymenoptera: Apoidea) in Puerto Rico. J. Agric. Univ. Puerto Rico 1976, 60, 639-660. [CrossRef]

21. Wong, K.M. Flowering, fruiting and germination of the bamboo Schizostachyum zollingeri in Perlis. Malays. For. 1981, $44,453-463$.

22. Bogdan, A.V. Grass pollination by bees in Kenya. Proc. Linnean Soc. 1962, 173, 57-60. [CrossRef]

23. Koshy, K.C.; Harikumar, D.; Narendran, T.C. Insect visits to some bamboos of the Western Ghats, India. Curr. Sci. 2001, 81, 833-838.

24. Wolowski, M.; Freitas, L. An overview on pollination of the neotropical Poales. Rodriguésia 2015, 66, 329-336. [CrossRef]

25. Ruiz-Sanchez, E.; Castro-Castro, A.; Clark, L.G. Chusquea septentrionalis sp. nov. (Poaceae: Bambusoideae) from the Madrean region in Durango, Mexico. Nord. J. Bot. 2017, 35, 546-551. [CrossRef]

26. Saunders, M.E. Insect pollinators collect pollen from wind-pollinated plants: Implications for pollination ecology and sustainable agriculture. Insect Conserv. Divers. 2018, 11, 13-31. [CrossRef]

27. Prieto-Baena, J.C.; Hidalgo, P.J.; Domínguez, E.; Galán, C. Pollen production in the Poaceae family. Grana 2003, 42, 153-159. [CrossRef]

28. Aboulaich, N.; Bouziane, H.; Kadiri, M.; del Mar Trigo, M.; Riadi, H.; Kazzaz, M.; Merzouki, A. Pollen production in anemophilous species of the Poaceae family in Tetouan (NW Morocco). Aerobiologia 2009, 25, 27-38. [CrossRef]

29. Ghitarrini, S.; Galán, C.; Frenguelli, G.; Tedeschini, E. Phenological analysis of grasses (Poaceae) as a support for the dissection of their pollen season in Perugia (central Italy). Aerobiologia 2017, 33, 339-349. [CrossRef]

30. Cruden, R.W. Pollen-ovule ratios: A conservative indicator of breeding systems in flowering plants. Evolution 1977, 31, 32-46. [CrossRef]

31. Subba Reddi, C.S.; Reddi, N.S. Pollen production in some anemophilous angiosperms. Grana 1986, 25, 55-61. [CrossRef]

32. Kaybeleva, E.I.; Yudakova, O.I. Pollen-ovule ratios in cereals with different mode of reproduction. Bull. Saratov Univ. Bot. Gard. 2015, 13, 148-154.

33. Bai, A.J.; Subba Reddi, C.S. Pollen productivity and pollen incidence in some potentially allergenic plants of Visakhapatnam. Adv. Pollen Spore Res. 1980, 5, 217-224.

34. McKone, M.J. Intraspecific variation in pollen yield in bromegrass (Poaceae: Bromus). Am. J. Bot. 1989, 76, 231-237. [CrossRef]

35. De Vries, A.P. Flowering biology of wheat, particularly in view of hybrid seed production-A review. Euphytica 1971, 20, 152-170. [CrossRef]

36. Sapra, V.T.; Hughes, J.L. Pollen production in hexaploid Triticale. Euphytica 1975, 24, 237-243. [CrossRef]

37. Nguyen, V.; Fleury, D.; Timmins, A.; Laga, H.; Hayden, M.; Mather, D.; Okada, T. Addition of rye chromosome 4R to wheat increases anther length and pollen grain number. Theor. Appl. Genet. 2015, 128, 953-964. [CrossRef]

38. Song, X.; Feng, J.; Cui, Z.; Zhang, C.; Sun, D. Genome-wide association study for anther length in some elite bread wheat germplasm. Czech J. Genet. Plant Breed. 2018, 54, 109-114.

39. De Vries, A.P. Some aspects of cross-pollination in wheat (Triticum aestivum L.). 3. Anther length and number of pollen grains per anther. Euphytica 1974, 23, 11-19. [CrossRef]

40. Smart, I.J.; Tuddenham, W.G.; Knox, R.B. Aerobiology of grass pollen in the city atmosphere of Melbourne: Effects of weather parameters and pollen sources. Aust. J. Bot. 1979, 27, 333-342. [CrossRef]

41. Piotrowska, K. Pollen production in selected species of anemophilous plants. Acta Agrobot. 2008, 61, 41-52. [CrossRef]

42. Tormo-Molina, R.; Maya-Manzano, J.-M.; Silva-Palacios, I.; Fernández-Rodríguez, S.; Gonzalo-Garijo, Á. Flower production and phenology in Dactylis glomerata. Aerobiologia 2015, 31, 469-479. [CrossRef]

43. Driessen, M.N.B.M.; Willemse, M.T.M.; Van Luijn, J.A.G. Grass pollen grain determination by light- and UV-microscopy. Grana 1989, 28, 115-122. [CrossRef]

44. Weber, R.W. Patterns of pollen cross-allergenicity. J. Allergy Clin. Immunol. 2003, 112, 229-239. [CrossRef]

45. Kraaijeveld, K.; De Weger, L.A.; Ventayol García, M.; Buermans, H.; Frank, J.; Hiemstra, P.S.; Den Dunnen, J.T. Efficient and sensitive identification and quantification of airborne pollen using next-generation DNA sequencing. Mol. Ecol. Resour. 2015, 15, 8-16. [CrossRef]

46. Bell, K.L.; De Vere, N.; Keller, A.; Richardson, R.T.; Gous, A.; Burgess, K.S.; Brosi, B.J. Pollen DNA barcoding: Current applications and future prospects. Genome 2016, 59, 629-640. [CrossRef]

47. Ghitarrini, S.; Pierboni, E.; Rondini, C.; Tedeschini, E.; Tovo, G.R.; Frenguelli, G.; Albertini, E. New biomolecular tools for aerobiological monitoring: Identification of major allergenic Poaceae species through fast real-time PCR. Ecol. Evol. 2018, 8, 3996-4010. [CrossRef] [PubMed]

48. Leontidou, K.; Vernesi, C.; De Groeve, J.; Cristofolini, F.; Vokou, D.; Cristofori, A. DNA metabarcoding of airborne pollen: New protocols for improved taxonomic identification of environmental samples. Aerobiologia 2018, 34, 63-74. [CrossRef]

49. Christensen, J.E.; Horner, H.T., Jr. Pollen pore development and its spatial orientation during microsporogenesis in the grass Sorghum bicolor. Am. J. Bot. 1974, 61, 604-623. [CrossRef]

50. Kirpes, C.C.; Clark, L.G.; Lersten, N.R. Systematic significance of pollen arrangement in microsporangia of Poaceae and Cyperaceae. Review and observations on representative taxa. Am. J. Bot. 1996, 83, 1609-1622. [CrossRef]

51. Furness, C.A.; Rudall, P.J. The tapetum and systematics in monocotyledons. Bot. Rev. 1998, 64, 201-239. [CrossRef]

52. Friedman, J.; Harder, L.D. Functional associations of floret and inflorescence traits among grass species. Am. J. Bot. 2005, 92, 1862-1870. [CrossRef] [PubMed] 
53. Beck, H.E.; Zimmermann, N.E.; McVicar, T.R.; Vergopolan, N.; Berg, A.; Wood, E.F. Present and future Köppen-Geiger climate classification maps at 1-km resolution. Sci. Data 2018, 5, 180214. [CrossRef]

54. Potdar, G.G.; Salunkhe, C.B.; Yadav, S.R. Grasses of Maharashtra; Shivaji University: Kolhapur, India, 2012; ISBN 81-8486-450-7.

55. Alexeev, Y.E. The family Poaceae. In Maevskyi P.F. Flora of the Middle Part of European Russia; KMK: Moscow, Russia, 2014; pp. 509-569, ISBN 5-04-099221-1.

56. White, T.J.; Bruns, T.; Lee, S.; Taylor, J. Amplification and direct sequencing of fungal ribosomal RNA genes for phylogenetics. PCR Protoc. Guide Methods Appl. 1990, 18, 315-322.

57. Kumar, S.; Stecher, G.; Li, M.; Knyaz, C.; Tamura, K. MEGA X: Molecular evolutionary genetics analysis across computing platforms. Mol. Biol. Evol. 2018, 35, 1547. [CrossRef]

58. Adobe Systems Inc. Adobe Photoshop, Version 22.5.1; Adobe Systems Inc.: Mountain View, CA, USA, 2021.

59. Connor, H.E. Flowers and floral biology of the holy grasses (Hierochloe and Anthoxanthum: Aveneae, Gramineae). Flora 2012, 207, 323-333. [CrossRef]

60. R Core Team. R: A Language and Environment for Statistical Computing. R Foundation for Statistical Computing; R Core Team: Vienna, Austria, 2021.

61. Stanley, R.G.; Linskens, H.F. Pollen: Biology, Biochemistry, Management; Springer: Berlin/Heidelberg, Germany, 1974; ISBN 978-642-65907-2

62. Beri, S.M.; Anand, S.C. Factors affecting pollen shedding capacity in wheat. Euphytica 1971, 20, 327-332. [CrossRef]

63. Erbar, C.; Langlotz, M. Pollen to ovule ratios: Standard or variation-a Compilation. Bot. Jahrb. Syst. 2004, 126, 71-132. [CrossRef]

64. Smith, D.C. Pollination and seed formation in grasses. J. Agric. Res. 1944, 68, 79-95.

65. Lehmann, C.; Rebele, F. Zum potential sexueller Fortpflanzung bei Calamagrostis epigejos (L.) Roth. Verh. Ges. Ökol. 1994, 23, 445-450.

66. Rebele, F.; Lehmann, C. Biological flora of Central Europe: Calamagrostis epigejos (L.) Roth. Flora 2001, 196, 325-344. [CrossRef]

67. Aiken, S.G.; Dore, W.G.; Lefkovitch, L.P.; Armstrong, K.C. Calamagrostis epigejos (Poaceae) in North America, especially Ontario. Can. J. Bot. 1989, 67, 3205-3218. [CrossRef]

68. Thoiba, K.; Pradeep, A.K. A Revision of Tripogon (Poaceae: Chloridoideae) in India. Rheedea 2020, 30, 325. [CrossRef]

69. Gaff, D.F.; Bole, P.V. Resurrection grasses in India. Oecologia 1986, 71, 159-160. [CrossRef] [PubMed]

70. Baumann, U.; Juttner, J.; Bian, X.; Langridge, P. Self-incompatibility in the grasses. Ann. Bot. 2000, 85, 203-209. [CrossRef]

71. Pfitzenmeyer, C.D.C. Arrhenatherum elatius (L.) J. \&. C. Presl (A. avenaceum Beauv.). J. Ecol. 1962, 50, $235-245$.

72. Cuguen, J.; Acheroy, M.; Loutfi, A.L.; Petit, D.; Vernet, P. Breeding system differentiation in Arrhenatherum elatius populations: Evolution toward selfing. Evol Trends Plants 1989, 3, 17-24.

73. Petit, C.; Lesbros, P.; Ge, X.; Thompson, J.D. Variation in flowering phenology and selfing rate across a contact zone between diploid and tetraploid Arrhenatherum elatius (Poaceae). Heredity 1997, 79, 31-40. [CrossRef]

74. Jürgens, A.; Witt, T.; Gottsberger, G. Pollen grain numbers, ovule numbers and pollen-ovule ratios in Caryophylloideae: Correlation with breeding system, pollination, life form, style number, and sexual system. Sex. Plant Reprod. 2002, 14, $279-289$.

75. Galloni, M.; Podda, L.; Vivarelli, D.; Cristofolini, G. Pollen presentation, pollen-ovule ratios, and other reproductive traits in Mediterranean legumes (fam. Fabaceae-subfam. Faboideae). Plant Syst. Evol. 2007, 266, 147-164. [CrossRef]

76. Alarcón, M.L.; Roquet, C.; Aldasoro, J.J. Evolution of pollen/ovule ratios and breeding system in Erodium (Geraniaceae). Syst. Bot. 2011, 36, 661-676. [CrossRef]

77. Ramirez, N.; Seres, A. Plant reproductive biology of herbaceous monocots in a Venezuelan tropical cloud forest. Plant Syst. Evol. 1994, 190, 129-142. [CrossRef]

78. Chorghe, A.R.; Tiwari, A.P. Effective lectotypification of three names in the genus Iseilema (Poaceae: Panicoideae). Kew Bull. 2021, 76, 857-858. [CrossRef]

79. Chandramohan, K.; Mahesh, Y. A taxonomic revision of the genus Iseilema Andersson (Poaceae) in India. J. Global Biosci. 2020, 9 , 7836-7868.

80. Kabeer, K.A.A.; Nair, V.J. Flora of Tamil Nadu-Grasses; Botanical Survey of India: Kolkata, India, 2009; pp. 1-524, ISBN 81-8177-031-5.

81. Hutchinson, C.S.; Seymour, G.B. Poa annua L. J. Ecol. 1982, 70, 887-901. [CrossRef]

82. Bell, C.R. Mineral nutrition and flower to flower pollen size variation. Am. J. Bot. 1959, 46, 621-624. [CrossRef]

83. Lau, T.-C.; Stephenson, A.G. Effects of soil nitrogen on pollen production, pollen grain size, and pollen performance in Cucurbita pepo (Cucurbitaceae). Am. J. Bot. 1993, 80, 763-768. [CrossRef]

84. Severova, E.E.; Yadav, S.R.; Sokoloff, D.D. Pollen morphology of Indian Aponogeton (Aponogetonaceae, Alismatales) and the problem of recognizing palynotypes in a taxonomically diverse and ancient genus. Phytotaxa 2020, 475, 187-200. [CrossRef] 